Fórum rovatunkban a Közjavak folyóirat korábbi számaiban megjelent tanulmányokhoz érkezett hozzászólásokat, vitaindítókat, reflexiókat, megjegyzéseket közöljük. A közös gondolkodás alapjainak továbbépítéséhez kíván fórumot biztosítani, továbbá a közjogi kutatások aktuális kérdéseinek megvitatásához, közvetlenül teret adva az aktuális témákkal kapcsolatos hírek megjelenésének, valamint a szakmai vélemények és különböző álláspontok közlésének a különböző jogágak közötti szabad és kötetlen kommunikáció jegyében.

\title{
KÖRNYEZETI KIHÍVÁSOK ÉS ÖNKORMÁNYZATI VÁLASZOK GONDOLATOK EGY KÖRNYEZETVÉDELMI JOGI KONFERENCIA KAPCSÁN ${ }^{*}$
}

Gyüre Annamária ${ }^{1}$

A környezeti problémák mindenhol, minden szinten megjelennek; megfigyelhetöek a nemzetközi együttmüködési törekvések, a kormányzati elképzelések, a regionálisan vagy települési szinten jelentkezö kihívások. A környezeti problémák köre széles, megjelenési formái sokszinüséget mutatnak, igy a megoldások is több szinten, az eszközök sajátos vegyitésével hozhatnak eredményt.

Az államok szintjén a központi kormányzat szerepe meghatározó, hiszen részben a kezében van az ökológiai problémák megoldásának kulcsa - jogi szabályozás kialakitása, pénzügyi eszközök megteremtése, intézményrendszer felállitása révén. Ugyanakkor az ökológiai kihívások a helyi közösségek életét befolyásolóan realizálódnak igazán, amire a helyi döntéshozóknak kell választ találniuk. A globális vagy nagyobb kiterjedésü problémákon túl (aszály, globális felmelegedés, vízellátási zavarok, mezögazdasági kártételek) a helyi életközösségek együttéléséböl fakadóan is jelentkeznek megoldásra váró helyzetek (hulladékgazdálkodási, zajvédelmi, természetvédelmi, stb. kérdések).

A helyi környezetvédelmet érintő kérdésekkel foglalkozott 2016. november 18-án a Debreceni Egyetem Állam- és Jogtudományi Karán megrendezett, A helyi önkormányzatok szerepe a környezeti jog és politika alakításában címü konferencia, a Magyar Tudomány Ünnepe debreceni programsorozatának zárásaként. A kutatócsoport a kar több tanszékén dolgozó kutatók együttmüködésén alapul, és az önkormányzati környezetvédelem körében végez jog-, állam-, szociológia- és politikatudományi szempontú, empirikus és elméleti kutatásokat. ${ }^{2}$ (A kutatásról bővebben lásd: Fodor

\footnotetext{
* DOI 10.21867/KjK/2016.4.6.

${ }^{1}$ Gyüre Annamária, tudományos segédmunkatárs, DE-ÁJK

2 A konferencia a Nemzeti Kutatási, Fejlesztési és Innovációs Hivatal által támogatott, 2015 szeptemberében indult (K 115530 azonosítószámú) projekt keretében, a debreceni jogi kar támogatásával került megrendezésre.
} 
László, Barta Attila, Fónai Mihály, Bányai Orsolya: Települési környezetvédelem Magyarországon: Egy kutatás előfeltevései. Tér és Társadalom, 2016/3. 19-39.)

A konferencia résztvevői azonban túlnyomó részben külső vendégek, elméleti és gyakorlati szakemberek, önkormányzatok és vállalkozások képviselöi voltak, akik nemcsak a szüken vett környezeti kérdéseket tekintették vizsgálatuk tárgyának, hanem a mai magyar önkormányzatok rendszerbeli elhelyezkedésével, azokat érintő kihívásokkal összefüggő áttekintést, elemzést is.

Az elöadások az önkormányzati környezetvédelmet több aspektusból vizsgálták. Az előadások sorát Bándi Gyula (PPKE JÁK) a „Fenntarthatóság, reziliencia és önkormányzatok" című előadásával nyitotta, amely a későbbi előadások felvezetéseként elméleti, megalapozó hátteret nyújtott a környezetvédelem és azon belül is önkormányzati környezetvédelem kérdéskörének. Ezt követően Pump Judit (Alapvető Jogok Biztosának Hivatala, PPKE ÁK), a „Helyi környezetpolitika - göröngyök az úton" címü elöadásában a környezetpolitika fogalmi lehatárolásával, valamint a helyi környezetpolitika elhelyezésével problémaorientált nézőpontból foglalkozott. Bányai Orsolya (DE ÁJK) a „Helyi stratégiák és környezetvédelem” címmel áttekintette a helyi szintü környezetvédelmi vonatkozású stratégia- és programalkotási lehetőségeket, illetve kötelezettségeket. Fodor László (DE ÁJK) „A környezetvédelmi szabályozás helyi szintje" címü előadásában a helyi környezetvédelmi szabályozás problémáinak felvázolásával foglalkozott. Ezt követően Némedi Erika (Alapvető Jogok Biztosának Hivatala) „Partnerségi-e az egyeztetés? - A településrendezési eszközök nyilvánosságának kérdései egy esettanulmányon keresztül" címmel tartott előadásában a helyi környezetvédelem gyakorlati megközelítése került elötérbe. Barta Attila (DE ÁJK) pedig „Önkormányzati társulások a helyi környezetvédelmi feladatok ellátásában” címmel a környezetvédelmi kérdésekkel kapcsolatosan az önkormányzati társulások szerepét vizsgálta. Fórika László, (Alapvető Jogok Biztosának Hivatala) „A vízhez való jog biztosítása az ombudsmani vizsgálatok tükrében" címü előadásában alkotmányjogi megközelítést alkalmazva vizsgálta a vízhez való jog biztosításának önkormányzati kötelezettségét. Pénzes Ferenc (DE ÁJK), „Az önkormányzatok szerepe és lehetőségei a helyi környezetpolitikában - az empirikus kutatások első tapasztalatai" címü előadásában a kutatócsoport által végzett kutatás empirikus, online kérdőíves felmérésének részeredményeit vázolta fel, a módszerre jellemző grafikonok, táblázatok és egyéb szemléltető eszközök segítségével.

Az előadásokat követő kerekasztal-beszélgetésen kötetlenebb formában vitatták meg az előadók a résztvevőkkel a felmerült kérdéseket. Ezen az általánostól kezdve a speciálisabb kérdéseken, az elméleti és gyakorlati problémák felvetésén át a gazdasági és jogi aspektusok felelevenítéséig számos megközelítés, probléma és magyarázat is szóba került.

A következőkben az előadásokon elhangzottakhoz, valamint a hozzászólásokhoz kapcsolódóan nyújtok egy szubjektív alapú áttekintést.

Több elöadásban is felmerült, hogy a helyi környezetvédelemnek és környezetvédelmi jogalkotásnak, döntéshozatalnak számos nehézséggel kell szembenéznie. A helyi jogalkotás köre szúkebb, mint indokolt lenne, az önkormányzatok döntési szabadsága erősen behatárolt az eszköz-hiány és a forráskivonás miatt. 2010 után az önkormányzatok korlátozott jogkörrel rendelkeznek, amiért is nehéz az ezekkel összefüggő kérdéseket elemezni. A környezeti kérdések szabályozása sokszor azzal 
összefüggésben történik, ami helyi szinten megjelenik, a folyamatosan változó jogszabályi környezet demotiválja a helyi döntéshozókat, és kiszámíthatatlanságot eredményez. Továbbá a hulladékgazdálkodási nehézségekkel összefüggésben merült fel, hogy a szabályozás változása mögött meghatározóan jelen vannak a konkurens üzleti modellek, ami általában megfigyelhető több környezetjogi szegmens vonatkozásában.

Ilyen körülmények között a települési szintnek nehéz megtalálnia azokat a szerepköröket és megoldási irányvonalakat, amelyeket szükségképpen fel kell vállalnia. Ehhez támpontot biztosít a reziliencia gondolata/alapelve, ${ }^{3}$ amely a környezetvédelemben még újnak hat, azonban számos elméleti kérdés megválaszolásához elengedhetetlen. A reziliencia, vagy rugalmas alkalmazkodás a fenntarthatóság alapelvével összekapcsolva azt hordozza magában, hogy az önkormányzati szintü környezetvédelemről való elképzeléseket új alapokra kell helyezni. Ez azt jelenti, mint ahogy Bándi Gyula megfogalmazza, hogy a települési szintü környezetvédelemnek hangsúlyosabbnak kell lennie. Ehhez azonban önmagát kell újrafogalmaznia. A környezeti kérdések szélesebb körüek, mint ahogy az elsőre megragadhatónak látszik. E körbe tartoznak azok a szabályozási tárgykörök is, amelyek még mérsékleten jelennek meg önkormányzati szinten. Ilyenek pl. a klímaváltozás során fellépő ökológiai változások és arra való alkalmazkodási lépések, vagy az energetikai kérdések köre, amelyek még nemzetközi, uniós vagy központi kormányzati szinten is csak körvonalazódni látszanak. A reziliencia jegyében fel kell mérni a bekövetkezö, várható hatásokat, cselekvési lehetőségeket és meg kell hozni a szükséges intézkedéseket. Annál is inkább, mert a hatások települési szinten lesznek leginkább érezhetőek a mindennapi ember számára. Ez indukálhatja az alulról jövő kezdeményezéseket. Ehhez nem feltétlenül kell újat kitalálni, a reziliencia igénye sem ez, csupán a meglévő keretek olyasfajta átalakítását igényli, ami a változó körülményekhez való hatékonyabb alkalmazkodást segíti elő.

Ennek alapja lehet az önkormányzatok által kötelezően megalkotandó környezetvédelmi programok, amelyekben településfejlesztési, közlekedési, természetvédelmi, köztisztasági, vízellátási témakörökön túlmenően többször rögzítnek pl. energetikai, klímaadaptációs kérdéseket is (pl. Debrecen, Keszthely, Mór ). Vannak olyan önkormányzatok is, amelyek ezeket külön dokumentumban rendezik (Szombathely, Veszprém, Hódmezővásárhely). De talán nem is a dokumentumok elnevezése a lényeges, sőt az integráció, a holisztikus szemlélet igényli ezeknek a területeknek az egymásra tekintettel való kezelését, ami egy egységes programban jobban megvalósítható. Valamint szükséges az együttműködés az önkormányzatok között is (akár társulások révén), vagy a civil szervezetekkel, a kormányzati szervekkel, stb., amely jobb (és transzparens, hatékony) döntéshozatalt alapozhat meg. Azok az önkormányzatok, amelyek valamely önkormányzati szervezet (pl. Polgármesterek Szövetsége) részei, a jobb információáramlás miatt hamarabb hoznak döntéseket e körben. Továbbá elkerülhetőek azok a helyzetek is, amelyek az országos és helyi szintü

\footnotetext{
${ }^{3}$ Bándi Gyula: A fenntartható fejlődés jogáról. Pro Futuro, 2013/1. szám, 11-30. o.
} 
jogszabályok kollízióját eredményezik. Ennek eklatáns példája a távhőellátást érintő jogalkotási anomáliák. ${ }^{4}$

Előfordul az is, hogy a központi szabályozás nem kínál megoldást egy helyi szintü környezeti probléma megoldására, amire példaként szolgál a Bogácson meghozott zajvédelmi szabályozás, amikor az önkormányzat egyes környezeti érdeket védendően hoz rendelkezést, szabályozási kompetencia hiányában. Ennek hátterében a külterületi pincesorra vonatkozóan határoztak meg zajvédelmi határértéket, mert zavarta a környéken élők nyugalmát, ugyanis az közel található a belterületi ingatlanokhoz.

Nem közvetlenül, hanem tágabb értelemben az uniós kvótakereskedelmi rendszer (EUETS) is kapcsolódik a helyi környezeti érdekekhez, amennyiben a klímaváltozásra visszavezethető káros folyamatok elszenvedője a lakosság, a települési szint, valamint a kvótarendszer alanyai, a vállalatok, müködése településekhez kapcsolódik.

Ugyanakkor megemlíthető az ETS komplementerének tekinthető erőforrás-megosztási szabályozás is, aminek ugyan címzettjei a tagállamok, de a tényleges cselekvés szintje a kormányzat alatt, a vállalati, az önkormányzati, a háztartási, a lakossági területeken van. Ez a szabályozás olyan kört takar, amely során a hulladékgazdálkodási, szolgáltatási, háztartási, közlekedési stb. szektor üvegházhatású gázkibocsátásának 10\%-os mérséklése a cél (2020-ra 2005-höz képest) - amelyek megvalósítása, valljuk be nehezen képzelhető el az önkormányzatok közremüködése nélkül. Ezek az ágazatok erősen az önkormányzatokhoz való kapcsolódásuk jegyében lesznek az elkövetkező évek/évtizedek klíma-/környezetvédelmi célterületei, amire a helyi, települési szintnek is reagálnia kell.

Azt láthatjuk, hogy a környezeti problémák által generált növekvő nyomásra az önkormányzatoknak válaszokat kell találniuk. Azonban ahhoz, hogy az eszközök, a fellépés területei megfelelőek, összehangoltak legyenek, nem szabad azokat magukra hagyni. Az együttműködés, a megfelelő információ rendelkezésre bocsátása, áramlása, a szakterületek közti integráció elmélyítése mindenképpen szükséges. Továbbá kívánatos a gazdasági szemlélet környezeti érdekekkel való összehangolása is, hiszen a gazdaság nem létezhet környezeti alapok hiányában.

\footnotetext{
${ }^{4}$ Fodor László: „Ki melegedni akar, füstöt is szenvedje.” A környezetvédelmi közérdek érvényesítése a távhő szabályozásában. Közjavak, II. évf., 2016/3. szám, 8-12. o.
} 